
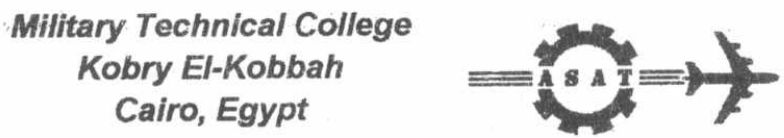

$10^{\text {th }}$ International Conference

On Aerospace Sciences\&

Aviation Technology

\title{
STUDY ON LUMINOUS PROPERTIES AND FORMULATIONS OF SOME ILLUMINATING COMPOSITIONS BASED ON UPE AS POLYMERIC BINDERS
}

\author{
E.S. NASR \\ R\&D department,National Organization for Military Production \\ Cairo,Egypt
}

\begin{abstract}
Illuminating compositions based on unsaturated polyester binders have been prepared. This work was directed towards the application of unsaturated polyesters as an oxygen containing binder for an illuminant composition. In this work, the effect of variation of the different formulating parameters on the processing and luminous characteristics of the illuminant composition has been investigated.

Those parameters include; changing type and content of metallic fuel such as magnesium and aluminum, inorganic oxidizer such as sodium,barium and strontium nitrate as well as the polymeric binder. The binder used was rigid and flexible unsaturated polyester. The effect of addition of sodium fluoride, poiy vinyl chloride, and graphite to the illuminant composition has been also studied.
\end{abstract}

This work shows that unsaturated polyester can be fairly used as a typical polymeric binder for preparing an illuminant composition of high luminous and mechanical characteristics . 


\section{INTRODUCTION}

Testing of many prior art flare compositions based on various binder formulations shows that high oxygen content in the binder improves efficiency. Cold polymerizing plastics such as unsaturated polyesers (Laminac) are typical examples of such oxygen rich binders ${ }^{[1]}$.

The intensity of an illuminating composition is largely determined by its temperature, which in turns depends on the stability of the reaction products. In order to generate grey body radiation which encompasses the spectral sensitivity of the human eye $(0.4-0.74 \mu \mathrm{rn}), 3000^{\circ} \mathrm{K}$ should be exceeded. Whereas this is possible using nitrates and perchlorates ${ }^{[2]}$ with alkaline earth metals as well as $\mathrm{Zr}$, Ti and $\mathrm{Hf}$, in practice $\mathrm{Mg}$ and $\mathrm{Al}$ are found to be best in terms of heat output, cost, and transparency to visible radiation.

The chemical ingredients in pyrochemical compositions can be devided into: fuels, oxidizers, binders (adhesives), and accessory materials. Metal oxidizers contribute their energy in the form of spectral emission at characteristic frequencies. The Common oxidizers include $\mathrm{Sr}\left(\mathrm{NO}_{3}\right)_{2} \mathrm{NaNO}_{3}$, and $\mathrm{Ba}\left(\mathrm{NO}_{3}\right)_{2}{ }^{[3]}$.

Most of the binders are natural and synthetic polymers. Among the synthetic polymers are silicon rubbers, epoxy resins, polyurethanes, carboxyl terminated polyesters cured by epoxy compounds, homopolymers and copolymers of vinyl monomers ${ }^{[4]}$ as alkylene oxides, acrylonitrile, and dienes.

Some compounds are added to the illuminant composition. to increase the intensity of light. These compounds are known as flame forming agents. A typical example of these compounds is sodium fluoride ${ }^{[5]}$. 
Strong hydraulic consolidation pressures, mostly, in the range of 6000 to $30,000 \mathrm{psi}$, are exerted on illuminating powder compositions within a steel or brass mold.

The burning time of the flare candle varies with the particle size and shape of the major ingredients.

This work is directed towards the study of the effect of different formulating parameters on the processing and luminous characteristics of the illuminant composition.

\section{EXPERIMENTAL}

\section{Formulation Of Illuminant Composition}

Illuminant compositions based on unsaturated polyesters have been prepared in the laboratory. The method of preparation includes the steps of mixing the prepolymer binder components, adding the metallic fuel followed by the oxidizer and other additives. After completion of mixing process the illuminant mixture is pressed while still wet inside a steel container.Then allowed to cure (for 16-24 hours) after pressing at room temperature to form an illuminant candle. Hydraulic consolidation pressure of about 14000 psi has been exerted.

In case of granulation process an evaporable diluent (acetone) has been added to the prepolymer binder and after completion of the mixing process the pyrotechnic composition incorporating the diluent mixture has been forced to pass through a sieve with $2 \mathrm{~mm}$ mesh to form granules. The curing and evaporation processes are then allowed to complete. This may be allowed to take place while the composition is still in granular form; the granules can then be pressed into a solid mass. Alternatively, the granules can be pressed together while the curing and evaporation processes are taking place which enables a lower pressure to be employed. In either case a mechanically strong mass having cured unsaturated polyester as the 
binder has been prepared. Materials used for the polymeric binder in the studied formulations and their characteristics are listed in table 1.

The preparation technique may be conducted either with the binder alone or with the binder-diluent mixture. The used binders were rigid and flexible unsaturated polyester. Methyl ethyl ketone peroxide as the polymerization catalyst was added to the styrenated polyester and mixed well. Then cobalt octoate as an accelerator to promote the curing process at room temperature was added to the previous mixture. The used oxidizers were sodium nitrate, barium nitrate and strontium nitrate, while $\mathrm{Al}$ and $\mathrm{Mg}$ powders were used as metallic fuels.

Various formulations using different types and contents of binder, oxidizer and metallic fuel have been prepared. Also different grain sizes of the oxidizers and fuels have been used. Sodium fluoride was used as an active flame forming agent. Tables 2, 4, 6 illustrates the detailed formulation for the prepared illuminant compositions.

The detailed method for preparation of the suitable binder composition is explained in preceding article ${ }^{[6]}$. The illuminant compositions were consolidated into a steel cylinderical containers (with $84 \mathrm{~mm}$ inner diameter) and cured at room temperature. The oxidizers and metallic fuels were used in bimodal composition $30 \%<50 \mu \mathrm{m} ; 70 \%$ between 50 and 150 $\mu \mathrm{m}$ for fine powder, and $30 \%<100 \mu \mathrm{m} ; 70 \%$ between 100 and $250 \mu \mathrm{m}$ for coarse powders. Sodium fluoride was used in grain size $<50 \mu \mathrm{m}$, while graphite $<100 \mu \mathrm{m}$ and PVC is of the emulsion type.

\section{Luminous and Explosive Characteristics:}

Measurement of candle power output and burning time was carried out using the channel light beam oscillograph type $\mathrm{H}$ 115. The ignition temperature and calorific value were determined by following the procedures outlined in analytical methods for powders and explosives. ${ }^{[7-8]}$. 


\section{RESULTS AND DISCUSSION}

To show the effect of variation of binder content on luminous characteristics, five illuminant formulations were prepared (Nos. 1-5 in Table 2). The luminous characteristics tabulated in table 3 and illustrated in Fig.(1) show that increasing the binder (UPE) content from $4 \%$ to $13.5 \%$ causes a pronounced decrease in candlepower output and burning rate. Also the efficiency increases up to a maximum value at binder content $9.3 \%$ by weight then it starts to decrease again. It is clear too, that the inflection point of the candle power output curve and the peak of the luminous efficiency curve corresponds, to the inversion of $\mathrm{Ba}\left(\mathrm{NO}_{3}\right)_{2}$ to $\operatorname{Sr}\left(\mathrm{NO}_{3}\right)_{2}$ mass ratio from 1:5 to $5: 1$ respectively. From table 2 it is clear that the decrease of the content of $\mathrm{NaF}$ (as the flame forming agent) from $3.8 \%$ to $1 \%$ causes a decrease in c.p.o. and luminous efficiency but a very slight change in b.r. Luminous ufficiency is defined by multiplying the candle power into time of burning and then devided by the mass of the illuminant composion( $\mathrm{cd} * \mathrm{sec} / \mathrm{gm})$.

To make a correlation between luminous characteristics and the binder content in illuminant compositions containing $\mathrm{Ba}\left(\mathrm{NO}_{3}\right)_{2}$ and $\mathrm{Sr}\left(\mathrm{NO}_{3}\right)_{2}$ in addition to $\mathrm{NaNO}_{3}$ (as the major portion of the oxidizer mixture), six samples (Nos. 7-12 in table 4) were prepared in variable content of UPE from 9\% up to $16.1 \%$. Table 5 and Fig. (2) show that the increase of binder content causes a decrease in c.p.o. and b.r. However, the efficiency increases slowly with the increase of binder up to $14.5 \%$ then decreases again. The inflection point of the c.p.o. curve and the peak point of luminous efficiency curve corresponds to the use of pure UPE as liner between the illuminant composition and the inner walls of the steel conatiner. The use of UPE liner as thermal insulation minimizes the energy loss from the burning candle and also prolonges the time of burning because it decreases the heating up of the remaining composition with hot combustion products by conduction through the container walls. At higher values of binder content $>14.5 \%$ the c.p.o. decreases dramatically due to 
cheminy formation and shortening of b.r. The addition of PVC by $1.8 \%$ to the illuminant composition causes a remarkable decrease in c.p.o. and luminous efficiency but no change nearly in b.r.,this may be attributed to the low temperature of dissociation of PVC and the endothermic nature of this reaction.

Another study was carried out aimed at illustrating the effect of using $\mathrm{NaNO}_{3}$ as the only oxidizer, the effect of grain size of $\mathrm{NaNO}_{3}$ and $\mathrm{Mg}$, the addition of graphite and finally the effect of variation of the oxd. / ful. ratio $^{[9]}$. The composition of the illuminant formulations shown in table 6.

The dependence of luminous characteristics on the different mentioned parametes is shown in table 7. It is clear from table 7 that the use of $\mathrm{NaNO}_{3}$ as oxidizer improves significantly the c.p.o. and luminous efficiency, also as the grain size of $\mathrm{NaNO}_{3}$ increases (up to $210 \mu \mathrm{m}$ ) the c.p.o. and luminous efficiency increase.

The same effect of grain size variation is shown for $\mathrm{Mg}$ which may be explained by the rapid decrease in burning time as the grain size decreases leading to decrease in luminous efficiency. The addition of $1 \%$ graphite causes an increase in c.p.o. and dramatic decrease in burning time, thus leading to a decrease in luminous efficiency.

The dependence of luminous characteristics on the oxidizer to fuel ratio is illustrated in Fig. (3) and Fig. (4). It is clear that, luminous efficiency increases with the increase of oxd./ful. from 0.43 to 0.52 then starts to decrease slightly again from 0.52 to 0.58 . However, the c.p.o shows slight increase and b.r. shows rapid increase in their values with the increase of oxd/ful Ratio to the value .58. This may be explained by the optimum stoichometry of the reactants at the value .52 followed by rapid decrease in burning time at .58 due to excess oxidizer leading to decrease in luminous : efficiency. 
The use of flexible UPE improves significantly all the luminous characteristics as shown in table 7. This may attributed to the lower content of styrene in flexible UPE compared to rigid UPE which means the minimizing of the bad effect of styrene on the luminous characteristics.

\section{CONCLUSION}

Illuminating compositions of attractive luminous characteristics could be obtained using unsaturated polyesters as an oxygen rich polymeric binders. The grain size of both oxidizer and fuel affects greatly the luminous characteristics of the prepared compositions. Sodium nitrate as oxidizer gives better results than $\mathrm{Ba}\left(\mathrm{NO}_{3}\right)_{2}$ and $\mathrm{Sr}\left(\mathrm{NO}_{3}\right)_{2}$.

\section{NOMENCLATURE}

UPE : unsaturated polyester

PVC : Poly vinyl chloride

cd : candle

b.r. : burning rate

r.m.f : rate of mass flow

c.p.o : candlepower output

oxd : oxidizer

ful : fuel

\section{REFERENCES:}

[1] Nasr E.S., "Effect of using some polymers on the characteristics of some energetic pyrotechnics" $24^{\text {th }}$ Int. conference of ICT, P 68-1, Karlsruhe, FRG, (1993).

[2] Weldon R.H. et al ., "Evaluation of the change in performance of pyrotechnic flash units by the substitution of Aluminum fuel by Hafnium, Cerium, Titanium and Zirconium", Australian Weapons and Research Establishment TM CPD 163 (1970).

[3] Varyonykh N.M. et al ., "Peculiarities of combustion of $\mathrm{Mg} / \mathrm{Sr}\left(\mathrm{NO}_{3}\right)_{2}$ and $\mathrm{Mg} / \mathrm{Ba}\left(\mathrm{No}_{3}\right)_{2}$ Mixtures" $29^{\text {th }}$ Int. Seminar of pyrotechnics, pp391396, Westminster, Colorado, USA, (2002).

[4]Hdhoud M.K et al .; "Pyrotechnics; Basic principles; technology and applications", Proceeding of $16^{\text {th }}$ ICT International conference 
combined with $10^{\text {th }}$ International pyrotechnics seminar, karlsruhe, FRG, (1985).

[5] Abdel Salam M., M.Sc. Thesis, chair of chemistry, military technical college, Cairo, Egypt (1986).

[6] Nasr E.S. "Effect of methyl ethyl ketone peroxide as catalyst and cobalt octoate as an accelerator for the copolymerization of unsaturated polysters with styrene", armed forces sci. res. Jour. - vol. XVII, No. 41, Cairo, June (1987).

[7]Bofors A.B. and N. Krut, "Analytical methods for powders and explosives", Sweden (1971).

[8] Yong L. and Lui F., "Ultraviolet, visible and infrared ignition of pyrotechnic compositions" $22^{\text {nd }}$ Int seminar of pyrotechnics, pp 167177, Fort Collins, colorado, USA, (1996).

[9] Hirata Norimasa et al., "Combustion of NaNO3 Based Energetic Pyrolants" $26^{\text {th }}$ Int. seminar of pyrotechnics, pp 163-169, Nanjing, Jiangsu, P.R. china (1999). 
Table 1 . Sources and Specifications of Materials of Polymeric Binders

\begin{tabular}{|c|c|c|}
\hline Materials & Specifications & Source \\
\hline Rigid unsaturated polyester & $\begin{array}{l}\text { Medium reactive isophthalic polyester } \\
\text { solution of } 33 \% \text { by wt. Styrene content }\end{array}$ & \multirow{4}{*}{$\begin{array}{l}\text { Egyptian } \\
\text { American } \\
\text { Company } \\
\text { for Paints } \\
\text { \&Coatings }\end{array}$} \\
\hline Flexible unsaturated polyester & $\begin{array}{l}\text { Resilient isopolyester solution of } 28 \% \\
\text { by wt. Styrene monomer content }\end{array}$ & \\
\hline Methyl ethyl ketone peroxide & $\begin{array}{l}\text { Colourless liquied, irritant used as } \\
\text { polymerization catalyst }\end{array}$ & \\
\hline Cobalt octoate & $\begin{array}{l}\text { As solution containing } 10 \% \text { by wt. of } \\
\text { cobalt octoate in styrene }\end{array}$ & \\
\hline
\end{tabular}

Table 2. Formulation of illuminant compositions containing barium and strontium nitrate.

\begin{tabular}{ccccccc}
\hline $\begin{array}{c}\text { Composition } \\
\text { mass \% }\end{array}$ & \multicolumn{6}{c}{ Constituents } \\
\cline { 2 - 8 } & UPE & AI & \multicolumn{1}{c}{ Mg } & NaF & Ba(NO3)2 & Sr(NO3)2 \\
\hline S1 & 4 & 5 & 57 & 4 & 5 & 25 \\
S2 & 6.8 & 4.9 & 55.3 & 3.8 & 4.9 & 24.3 \\
S3 & 9.3 & 4.7 & 53.9 & 3.8 & 4.7 & 23.6 \\
S4 & 11.1 & 4.6 & 52.8 & 3.7 & 23.2 & 4.6 \\
S5 & 13.5 & 4.5 & 51.4 & 3.6 & 22.5 & 4 \\
S6 & 9.1 & 5.7 & 56.5 & 1 & 23.9 & 4.8 \\
\hline
\end{tabular}

Table 3 . Luminous characteristics of illuminant compositions containing barium and strontium nitrate

\begin{tabular}{|c|c|c|c|c|c|c|}
\hline \multicolumn{2}{|l|}{$\begin{array}{c}\text { Formulations } \\
\text { No.s }\end{array}$} & $\begin{array}{c}\text { Burning } \\
\text { Rate }(\mathrm{cm} / \mathrm{s})\end{array}$ & $\begin{array}{c}\text { Mass Flow } \\
\text { Rate. } \\
(\mathrm{g} / \mathrm{s})\end{array}$ & \multicolumn{2}{|c|}{$\begin{array}{c}\text { Candle Power } \\
\text { Output } \\
\text { (cd) }\end{array}$} & $\begin{array}{l}\text { Luminous } \\
\text { Efficiency } \\
\text { (cd.s/g) }\end{array}$ \\
\hline SI & & 1.25 & 98 & 1,91 &, 000 & 13,500 \\
\hline S2 & & 0.59 & 44.8 & 1,36 &, 000 & 30,400 \\
\hline S3 & & 0.47 & 36 & 1,11 &, 000 & 31,000 \\
\hline S4 & & 0.57 & 43.6 & 992 & 000 & 22,800 \\
\hline S5 & & 0.45 & 33.9 & 522 & 000 & 15,400 \\
\hline S6 & & 0.60 & 45.5 & 797 & 000 & 17,500 \\
\hline \multicolumn{7}{|c|}{$\begin{array}{l}\text { Table 4. Formulation of illuminant compositions containing barium, } \\
\text { strontium and sodium nitrate. }\end{array}$} \\
\hline \multirow{2}{*}{$\begin{array}{l}\text { Composition } \\
\text { mass } \%\end{array}$} & \multicolumn{6}{|c|}{ Constituents } \\
\hline & UPE & $\mathrm{Mg}+\mathrm{AL}$ & $\mathrm{NaNO}_{3}$ & $\mathrm{Ba}\left(\mathrm{NO}_{3}\right)_{2}$ & $\mathrm{Sr}\left(\mathrm{NO}_{3}\right)_{2}$ & PVC \\
\hline S7 & 9 & 62.0 & 22.0 & 5.0 & 4.0 & - \\
\hline S8 & 13.1 & 60.0 & 19.1 & 4. & & - \\
\hline S9 & 14.5 & 59 & 18.8 & 4. & 3. & - \\
\hline *S 10 & 14.6 & 59.2 & 18.7 & 4.7 & 3.8 & - \\
\hline *S11 & 15 & 57.9 & 18.7 & 4.7 & 3.7 & - \\
\hline *S 12 & 16.1 & 57.1 & 18.4 & 4.6 & 3.7 & - \\
\hline $\mathrm{S} 13$ & 14 & 57.5 & 18.6 & 4.6 & 3.7 & 1.8 \\
\hline
\end{tabular}


Table 5. Luminous characteristics of illuminant compositions containing barium, strontium and sodium nitrate

\begin{tabular}{ccccc}
\hline $\begin{array}{c}\text { Formulations } \\
\text { No.s }\end{array}$ & $\begin{array}{c}\text { Burning } \\
\text { Rate }(\mathbf{c m} / \mathbf{s})\end{array}$ & $\begin{array}{c}\text { Mass Flow } \\
\text { Rate } \\
(\mathbf{g} / \mathbf{s})\end{array}$ & $\begin{array}{c}\text { Candle Power } \\
\text { Output } \\
\text { (cd) }\end{array}$ & $\begin{array}{c}\text { Luminous } \\
\text { Efficiency } \\
\text { (cd.s/g) }\end{array}$ \\
\hline S7 & 0.51 & 42.9 & $1,539,000$ & 36,100 \\
S8 & 0.38 & 31.8 & $1,130,000$ & 37,100 \\
S9 & 0.34 & 28.4 & $1,018,000$ & 35,900 \\
$*$ S10 & 0.26 & 20.8 & 825,000 & 39,600 \\
$*$ S 11 & 0.25 & 20 & 538,000 & 37,000 \\
$*$ S 12 & 0.24 & 19 & 704,000 & 21,400 \\
S13 & 0.35 & 27.8 & 758,000 & 27,00 \\
\hline
\end{tabular}

Table 6. Formulation of illuminant compositions containing sodium nitrate only

\begin{tabular}{|c|c|c|c|c|c|c|c|}
\hline \multirow{3}{*}{$\begin{array}{l}\text { Composition } \\
\text { mass } \%\end{array}$} & \multicolumn{7}{|c|}{ Constituents } \\
\hline & \multicolumn{2}{|c|}{ NaNO3 } & \multicolumn{2}{|c|}{$\mathrm{Mg}$} & \multirow[t]{2}{*}{ Graphite } & \multirow{2}{*}{$\begin{array}{l}\text { Other } \\
\text { Additives }\end{array}$} & \multirow{2}{*}{$\frac{\text { oxd }}{\text { Ful. }}$} \\
\hline & Fine & Course & Fine & Course & & & \\
\hline $\mathrm{S} 14$ & 30.4 & - & - & 48.4 & - & 21.2 & 0.58 \\
\hline S15 & 30.4 & - & 24.2 & 24.2 & - & $2 i .2$ & 0.58 \\
\hline S:6 & 27.9 & - & - & 50.1 & - & 22.0 & 0.52 \\
\hline S17 & 24.4 & - & - & 52.8 & 1 & 21.8 & 0.43 \\
\hline $\mathrm{S} 18$ & 24.6 & - & - & 53.4 & - & 22.0 & 0.43 \\
\hline S19 & - & 27.9 & - & 50.1 & - & 22.0 & 0.52 \\
\hline **S20 & - & 28.7 & - & 49.2 & - & 21.8 & 0.54 \\
\hline
\end{tabular}

Table 7. Luminous characteristics of illuminant compositions containing sodium nitrate only

\begin{tabular}{ccccc}
\hline Formulations No.s & $\begin{array}{c}\text { Burning } \\
\text { Rate }(\mathbf{c m} / \mathbf{s})\end{array}$ & $\begin{array}{c}\text { Mass Flow } \\
\text { Rate } \\
(\mathrm{g} / \mathrm{s})\end{array}$ & $\begin{array}{c}\text { Candle Power } \\
\text { Output } \\
(\mathbf{c d})\end{array}$ & $\begin{array}{c}\text { Luminous } \\
\text { Efficiency } \\
\text { (cd.s/g) }\end{array}$ \\
\hline S14 & 0.23 & 18.2 & $1,070,000$ & 58,000 \\
S15 & 0.29 & 23.3 & $1,031,000$ & 41,000 \\
S16 & 0.18 & 14.3 & 917,000 & 63,000 \\
S17 & 0.32 & 26.9 & $1,375,000$ & 51,000 \\
S18 & 0.16 & 13.2 & 780,000 & 59,300 \\
S19 & 0.21 & 16.9 & $1,136,000$ & 67,000 \\
$* *$ S20 & 0.23 & 17.9 & $1,397,000$ & 77,900 \\
\hline
\end{tabular}

Note: - In tables 4 and 5 the symbole $\left({ }^{*}\right)$ means with the use of UPE as thermal insulation.

- In Tables 6 and 7 the symbole $\left({ }^{* *}\right)$ means that the binder used is flexible unsaturated polyester, other additives means the sum of $\mathrm{Al}, \mathrm{NaF}$ and UPE. 


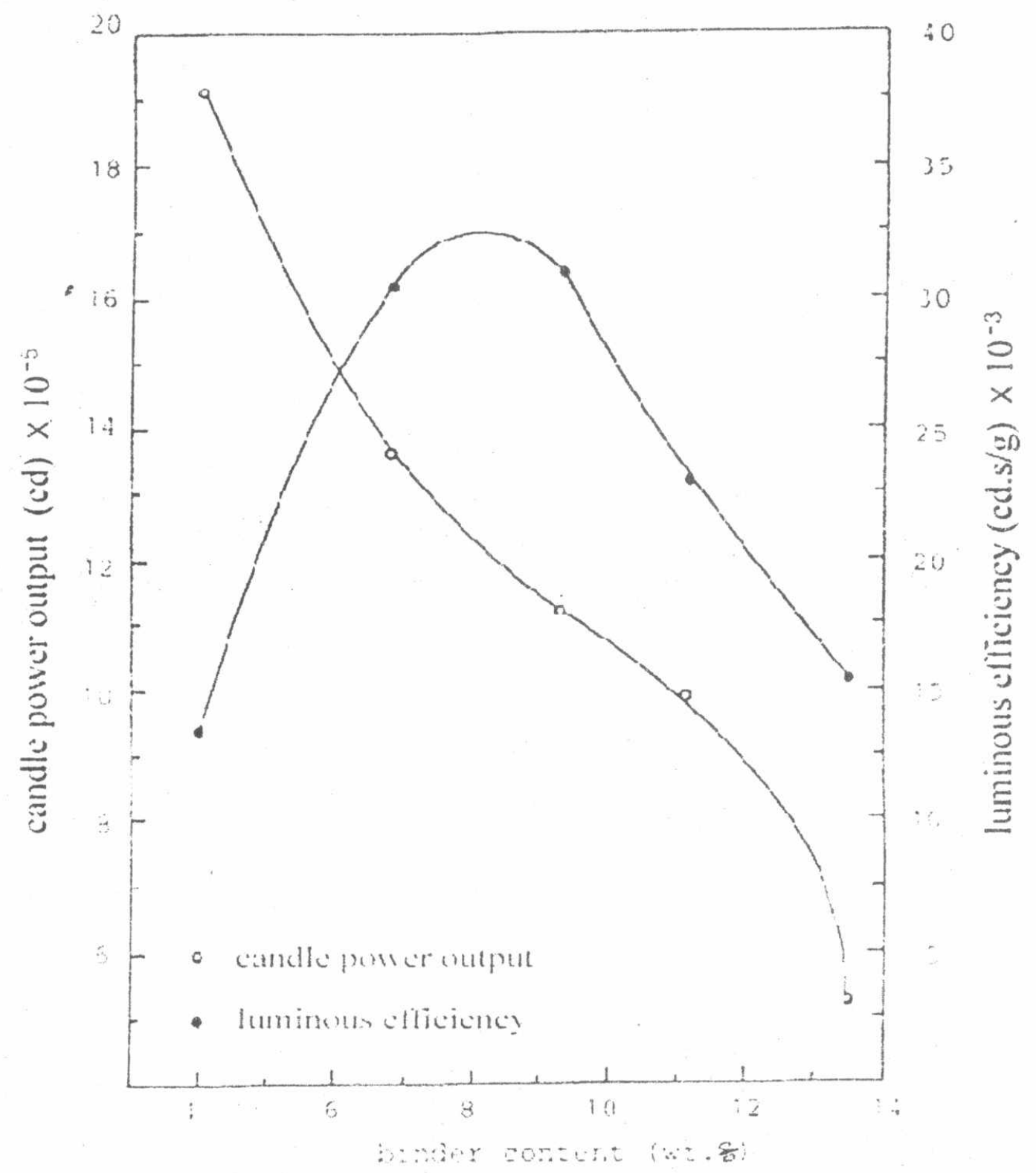

Fig. (1): lillect of binder contem on candle poner

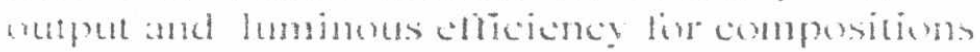
contaning harium and strontium nitalle. 


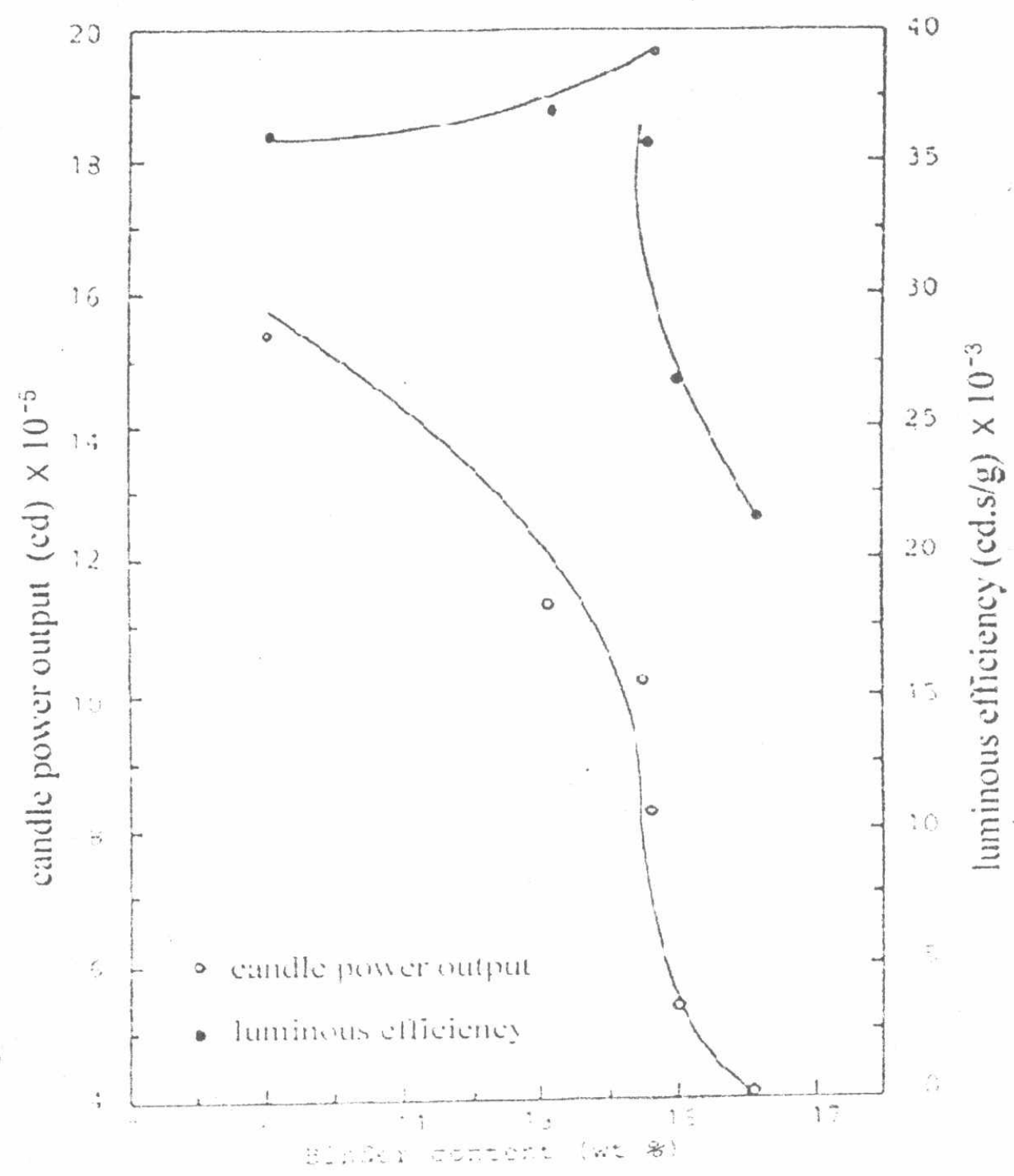

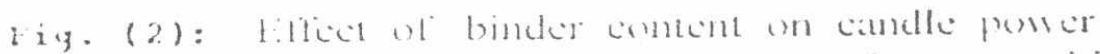
entput and laminums elliciones lor compositions combinimg bartum. strontitun and sodium nitrats. 


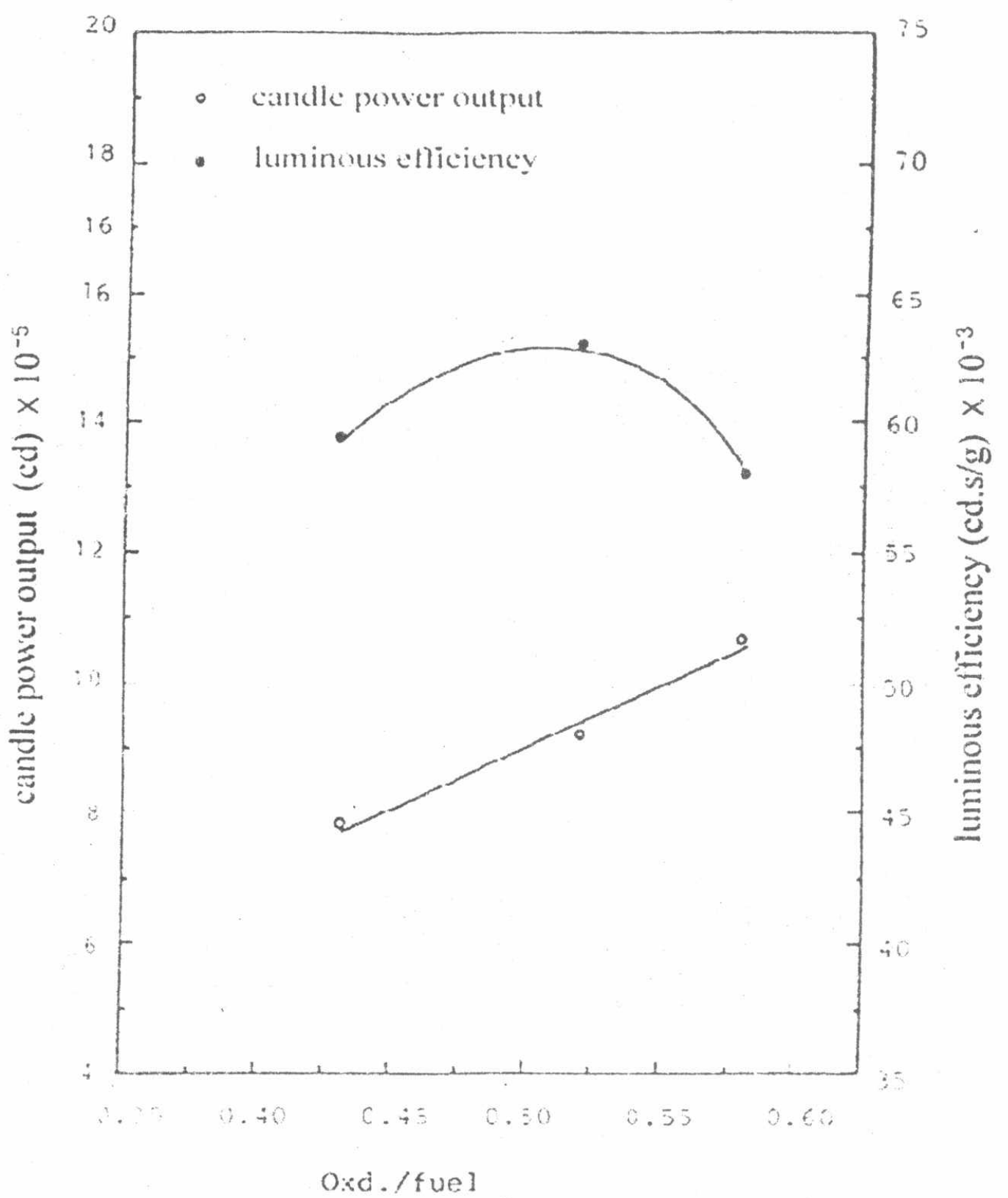

Fis. (3): Lffect of varying the oxidizer to fusl ratio on candle power output and luminous efficiency for compositions containing sodium nitrate only. 


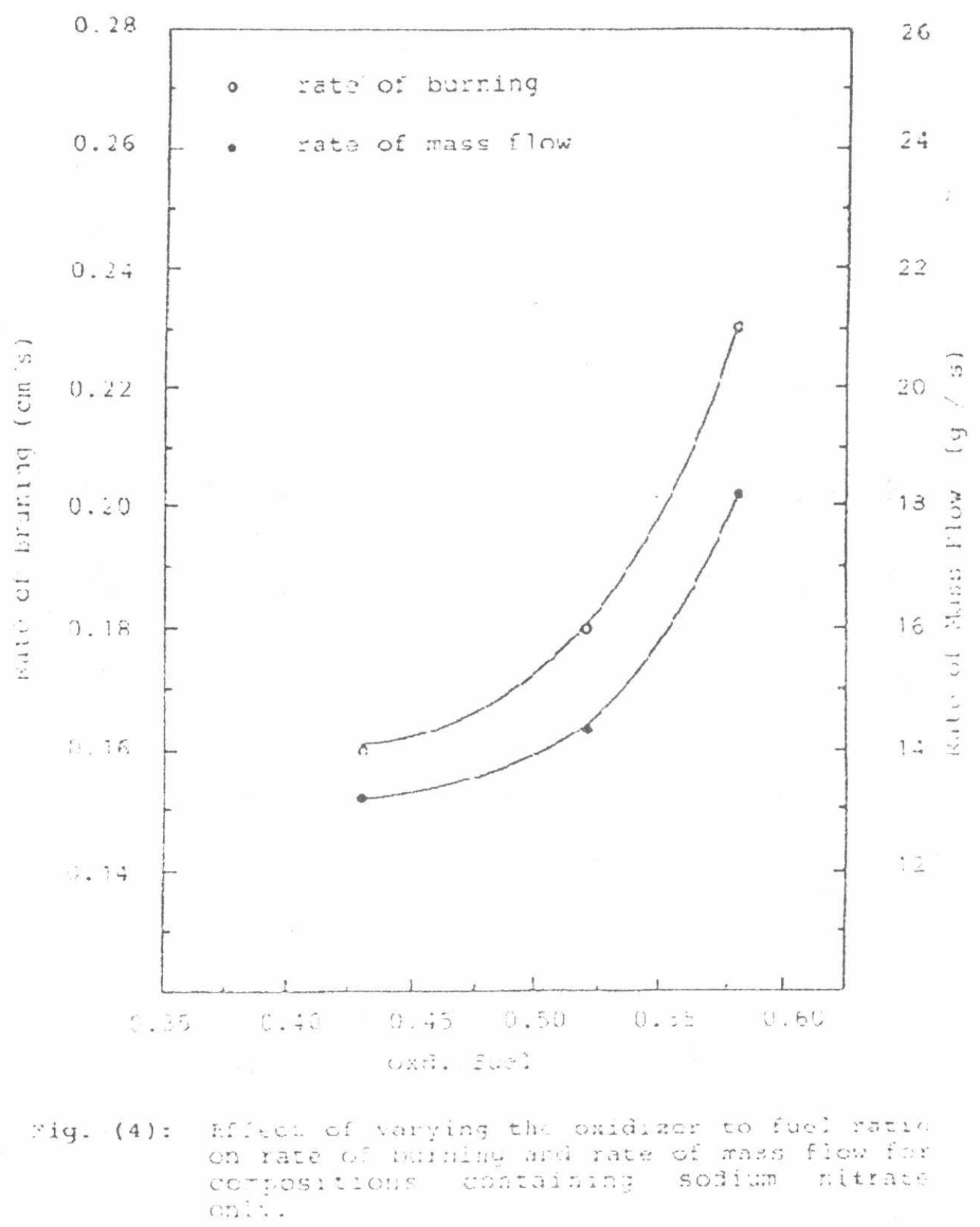

